\title{
LITERATURE FOR 1915 ON ANTS AND MYRMECOPHILS
}

\author{
MORRIS M. WELLS \\ Unwersaty of Chrcago
}

Bonner (1) presents a careful study of the wintering activities of Formica picea, beginning his observations in January. At this time the moor in which he made his studies was frozen solid to a depth of $1(0-15 \mathrm{~cm}$. The air temperature in the day time was about $7^{\circ}$ centigrade but it dropped to $-10^{\circ}$ at night. Nests of F. picea were chopped out of the frozen sphagnum and the ants were often found clumped together in the center of the nest and apparently frozen solid. An hour in a warm room restored them to normal activity. Bonner found that the large ants tended to form the center of the clump in the winter nest while the smaller, younger ones were often outside and perhaps not in the main clump but scattered through the galleries. Bonner also reports some experiments performed to determine the effect of submergence in water upon ants His results confirm those of other workers who have found that ants can live under water for hours in some cases.

Bonner (2) discusses the matter of the parasitism of Lasius fuliginosus on I umbratus in connection with the color of the nest coverings and lining of the galleries and also with regard to the behavior of L. fuliginosus toward Claviger longicornis which latter is a normal guest of L. umbratus. He experimented by placing a specimen of $\mathrm{C}$. longicomis in a nest of L. fuliginosus. The ants touched the beetle but did not pay any special attention to it. Two weeks later he took the beetle out of the nest. It had not been harmed. Bonner thinks that the beetle may start development in the umbratus nest but that the larger number of host individuals present with the coming in of fuliginosus may result in conditions that are more favorable to the development of the beetle than those existing in the nest when L. umbratus 
is in charge. This suggestion is made by Bonner to explain the finding of over 100 specimens of C. longicornis in a fuliginosus nest by Rosenberg in 1911. The difference in the color of the umbratus and the fullginosus nests he attributes to the oxidation of the nest materials which at first are light and yellowish but later turn black

Brun (3) published this book in 1914. It is a critical experimental study of ant behavior and a contribution to the mneme theory. It is listed here as it is a rork that should not go unrecorded in a list of ant literature.

Crawley (5) records observations regarding the behavior of fertulized females of Lasius umbratus. He states that such females at once devour one or more workers of L. niger if the latter are avalable The author thinks that this act produces the proper odor. physiological state or other condition necessary for the acceptance of the umbratus female into the nests of L. nuger. He found that queenless colonies of L. nger accepted these queens readily while they usually killed queens that were introduced into their nest before they had eaten a niger worker. Even L. niger colonies with queens did not kill the umbratus queens for some time if the latter had previously eaten a niger worker.

Crawley (6) here gives a list of ants collected in British Guiana by Mr. E. Bodkin. With many of the species he gives rather full habitat and breedng notes making the paper one of considerable interest.

Davis ( 7 ) found on July 26, 1914, on Long Island, a nest of Formica fusca var. subsericea that measured 18 feet in diameter. He noted that while the ants of this species are usually not very pugnacious those of this nest seemed to be quite vicious. The nest was in an open wood of pines and oaks. It was apparently the work of one colony.

Donisthorpe's book (8) on ants has received mention in the Entomological Record (1915) p. 237 and in Science (1916) p. 316-18. These reviews have been extremely favorable The book stands out as the important publication on ants in the year 1915. As is to be expected in so large a publication many phases of the subject of ants and their relationships are discussed. In general the material can be divided into a first part which deals with the external and internal anatomy of ants, a second part that treats of ant physiology and a third division that dis- 
cusses fully the psychology of ants. The book contains many original observations on the behavior of ants especially in the section devoted to Lasius. In the psychological discussion the author speaks of the ants throughout as though they were possessed of human consciousness. This is hardly justifiable at the present stage of our knowledge.

Donisthorpe (9) here records observations on the marriage flights of Donisthorpe sp. (Lasius sp.). $\mathrm{He}$ calls attention to the fact that these flights seem to be timed to some extent by weather conditions such as temperature, humidity, etc.

Elliott (10) describes fungi found in the nests of two British ants (Lasius niger and L. umbratus). The characteristic fungi were found in all the nests examined and no other species were found. The author thinks that perhaps the ants weed out the foreign species

Emery (11) in 1908 and 1909 succeeded in starting two experimental societies of Polyergus rufescons. These colonies were united in 1910 and the single resultant colony has been lept going since that time. In the present paper the author tells of taking the nest of Amazons into his garden where he opened it and allowed the ants to explore the surrounding territory. He was thus enabled to make detailed observations on the behavior of the ants. He observed them while they raided colonies of Formica fusca var. glebaria and F. rufibarbis. In July 1914 the ants were allowed to establish themselves in the soil in a courtyard of his villa. For the remainder of the summer and up to Oct. 2, the ants made sorties into the surrounding. territory but got no plunder as there were no nests of slave species in the yard. Emery believes that workers of the Amazons, leaving the nest singly, discover nests of slave species and returning, determine at least the initial direction taken by the army when it goes out He noted that most of the sorties occur late in the afternoon, usually between 4.20 and 7:00 P. M.

Flint (12) records observations made every night for nearly two months on movements of Lasius niger americanus at Bloomington, Ill. It was frequently noted that on warm nights when the ants were very active they would attack and kill many small insects that came near their nests.

Jones (13) in a short paper includes ants among the insects that carry the spores of pear blight in California. The list given 
by him is as follows: honey-bees, flies, ants, pear thrips, and apple aphids.

Mann (14) here gives some ecological data that is of value. In the main the paper is concerned with the description of a new species that is, according to the author, an addition to the species that occur at isolated points on the north coast as relicts of the ancient coastal plain fauna.

This paper by Mann (15) is largely a description and listing of other insects that the author has found in the nests of ants in Hayti. There are however occasional notes concerning the behavior of the ants and their guests. He records the following families of insects as occurring as guests in the nests of ants: Gryllidae, Cercopidae, Membracidae, Lathridiidae, Bethylidae, Syrphidae.

Morrill (16) in working on remedies for the suppression of the damage of the harvester ant in Arizona, reports that he has found that Carbondisulphide cannot be forced into the galleries of the ants even with a high pressure pump. He found that London purple kills the ants readily and with little expense attached to the treatment of the soil. He states that $\$ 1.17$ worth of the poison killed the ants in ten acres of ground where the nests of the ants were estimated to occupy one and one fourth acres.

In this paper Morrill (17) reports that carbondisulphide can be used successfully in combating the harvester ant in Arizona if the liquid is introduced into the nest and the hill then covered with a galvanized tub.

Smith (18) states that termites are damaging the lemon trees in the vicinity of Germantown, California.

In this account by Snyder (19) we have a very important and valuable addition to our knowledge of the biology of our North American termites. The account is based largely upon invest1gations carried on in 1910 and 1911 as to the character and extent of damage done to telephone and telegraph poles, mine props, etc., by wood boring insects. The investigation showed termites to rank among the most destructive agencies attacking crude and finished forest products. The species that he has considered are distributed widely over the United States.

The booklet is divided into a number of sub heads as follows: Classification, history, biological experiments, communal organization, polymorphism (different castes), life cycle, canni- 
balism, situation of the different forms in the nest, the nuptial flight, the establishment of new colonies, the royal pair and other reproductive forms, association with ants, termitophilous insects, parasites, damage to forest products, preventatives, remedies and immune woods. The paper contains reports upon a considerable number of experiments of one kind and another. There are also recorded many interesting original observations. Concerning the relation of termites to ants the author says that while ants and termites are commonly found inhabiting the same $\log$ or stump, yet ants are the enemies most to be feared by termites, as they will capture and carry away the members of a disorganized colony. Ordinarily the relations between termites and ants seem to be neighborly and peaceful. If the termite colony is opened up and disorganized, the ants at once take advantage of the opportunity and carry away the termites which offer but little resistance. Ants of several species may be attracted to such a helpless colony from a distance. The soft bodied soldiers are apparently not very effective in such an emergency, although in the narrow channels of the colony, where the powerful head with open mandibles is the only front presented to the marauding ants, they afford some protection to the colony.

Two species of carpenter ants (Camponotus pennsylvanicus, Mayr and Cremastogaster lineolata Say) are the ants which more commonly have been found associated with termites in eastern U. S. The latter species, due to its small size and rapid movements is a most formidable enemy.

Ants greatly diminish the number of the colonizing individuals at the time of the swarm, carrying them away as they are running about on the ground. Soldiers and workers guard the breaches from which the sexed adults have emerged.

Theobald (20), describes several new species of Myrmecophilous aphides and gives some behavior notes.

Turner (21) watched the mating activities of Lasius niger in St. Louis on Sept. 17, 1913. The entire mating behavior except the copulatory act was observed. In discussing these activities he points out that they are not readily explainable upon the basis of simple tropisms. He states that at this time he observed Formica species, present at the mating activities of Lasius, to be eating the Lassius males and sometimes the females also. 
Wheeler (22) outlines the question of the spinning of cocoons by ant larvae and calls attention to the fact that in the families Dorylinae, Myrmicinae, and Dolichoderinae the larvae never spin cocoons before pupation. He further points out that he has already published evidence as shown by the ants found in Baltic amber that there must have been forms with naked pupae at least two million years ago This would seem to settle conclusively, in the negative, any question as to the recent origin of the non-spinning habits of certain ant larvae The fact that the mature ant larvae cannot spin its cocoon without first being buried in a small mass of rubbish or in the earth makes it possible that the origin of the non-spinning habit is the result of a dropping out of this burying behavior upon the part of the adults rather than to a loss of spinning ability upon the part of the larvae. Wheelér cites a considerable list of ant species in which the larvae are great spinners but in which the spinning act vities go toward the making of a nest for the entire colony and the larxae never spins a cocoon for itself. As an example of this altrustic behavior the author records some observations which he made in Australia on Oecophylla virescens. He spent some time observing under favorable conditions the nest making activities of this speces which makes its nest by weaving together the leaves on a branch of a tree. The weaving is done by the adults but the larvae furnish the silk and are carried about in the mandibles of the adult and used as a shuttle until their supply of silk is exhausted. He noted also that young larvae were most commonly used Most of the work is done from the inside of the nest and is therefore not easily observed. Wheeler, however, fortunately saw part of the work being done on the outside of the nest.

In the latter part of the paper Wheeler discusses briefly coloration of ants in general. 1. Some ants are white or light colored These forms usually live in the dark. 2. A number of species exhibit a progressive development from red, brown or black to the interference colors. This is noticeable in ants living in hot dry sunny climates. Many of the Australian ants show interference colors. 3. There are large eyed tropical ants that are black and yellow with red spots and bands. Their general appearance is made more striking by the presence of a white or 
golden pubescence. The ants in moist places usually show little or no pubescence.

Wheeler (23) here gives some habitat data along with a description of a new variety of Formica fusca. He found this new variety in a peat-bog near Petersham, Mass. The author also gives a list of the ants one is likely to find in the cold bogs of the Northern United States, and British America.

\section{REFERENCES}

1. Bonner, $W$ Die Ueberwinterung von Formica picea and andre biologische Beobachtungen. Brol. Cent., 35, 65-77.

2. Bonner, W. Der temporare soziale hyperparasitismus von Lasius fuliginosus und seine Bezıchungen zu Claviger longicornis. Zeit. f. Wiss. Insektbrol., 11, $14-20$

3. Brun, R. Die Raumorientierung der Ameisen und das Orientierungs-problem $1 \mathrm{~m}$ allegememen. Jena, Gustav Fischer, 1914, pp. VIII2 +34. jo figs. B1bliography with 124 titles.

4 ConNetz, $V$. Observations nocturnes de trajets de fourms. Rev. Suisse Zool., 22, 581-95.

5. CRAWLEY, W. C A remarkable marriage flight of ants and some theories Entom. Record, 27, 205-6.

6. Crawiey, $\mathbb{W}$. A Ants from British Guiana. Ann and Mag. of Nal. Hzst, London, 17, 366-78.

7 Davis, $W$ T. A Long Island ant's nest $18 \mathrm{ft}$. in diameter. Jour. of $N$. Y. Ent. Sac., 1915, 69

8. Dosistronpe, J, $K$. British Ants, Their life historv and Classification. Wm. Brendon and Sons, Ltd pp. $\mathrm{IV}+373 ; 18$ pls. 92 figs.

9. Donistionpe, H. Marriage flights of Donisthorpea species on August 8th. Entom Record, 27, 206.

10. Elliotr, J.S. Bayliss Fungi in the nests of ants. Trans. Brit Mycol Soc., $5,138-42$.

11. Emerz, C Histoire d'une societe experimentale de Polyergus refescens Rev. Suzsse Zool, 23, 385-400.

12. Fuiv, W. P. On the capture of living insects by the cornfield ant (Lasius niger americanus) Jour. Eron Entom, 7, 476-478.

13. Jones, B. J. The Natural modes of distribution of pear bhght in California. Mo. Bull. Com. Hort. Cal., 3. Also U. S. Dept Agr., 33.

14. Maxs, W. M A new form of a southern ant from Naushou Island, Mass. Psyche, 22, 51.

15. ManN, W. M Some Myrmecophilous insects from Haytı. Psyche, 22, 161-66.

16. Morrill, 1. W. Ant, harvester, remedies U.S Dept of Agrac., 32, 549-50.

17. Morrill. Ants, harvester, remedies U S. Dept. Agre, 33, 57.

18. Smrrir, H S Termites (Insect Notes) Cal. Comm Hort , 4, 53.

19. SNYDER, T. E Insects injurious to forests and forest products Biology of the termites of the eastern United States with preventatıve and remedial measures, U.S. Dept Agric. Bull. Bur. Ent. No. 94, Pt. 2. pp. V+13-88.

20. New Myrmecophilous aphides. Entom. Record, 27, 52.

21. Turnen, C. H. The mating of Lasius niger. Jour. of Animal Behav', 5, 33740.

22. WHEELER, W M. On the presence and absence of cocoons among ants, the nest spinning habits of the larvae and the significance of the black cocoons among certain Australian species. Ann. of Entom. Soc. Am., 8, 323-12.

23. WheELer, W. M. A new bog Inhabiting variety of Formica fusca. Psyche, 22, 203-6. 